1741

An investigation of the optimal boundary between public and private production.

Harry Huizinga

Søren Bo Nielsen

The World Bank

Policy Research Department

Finance and Private Sector Development Division March 1997 


\section{Summary findings}

Huizinga and Nielsen investigate the optimal boundary between the public and private production sectors. They use a model in which government and private production coexist - in which a range of production activities can be carried out by either the government or the private sector.

In effect, the government determines which activities to maintain within the public sector and which to privatize. In choosing the sectoral boundary, the government trades off the relative inefficiency of marginal government production against the private investment distortion created by tax policy.

In an open economy, the private investment decision is distorted by a source-based income tax. In a closed economy, the private investment decision is distorted by either a private investment tax or a savings tax. Either tax produces a wedge between the gross return on investment and the net-of-tax return received by savers. Because of this tax wedge, the private cost of capital exceeds the shadow cost of public capital.

Optimally, the government sector is shown to be "too large" in the sense that the government carries out some activities in which it has an efficiency disadvantage and the private sector has an efficiency advantage. And it invests more in those activities than the private sector would. Generally the size of the government sector is related positively to the investment tax wedge.

The level of investment taxes - and thus the size of the state production sector - may be affected by tax competition in the international economy. As international capital becomes more mobile, there seems to be more scope for international (investment) tax competition. As a result of tax competition, perhaps, corporate income tax rates have been on a downward trend in European countries. In Europe, the general lowering of corporate income tax rates has coincided with a trend toward privatizing government activities.

Huizinga and Nielsen focus on the relationship between capital income taxes and the size of the government production sector. Analogously, one could consider the relationship between labor income taxes and the size of the state sector. In that instance, the model predicts that a formerly state-owned enterprise, after privatization, reduces its payroll. Privatization also seems to lead to reduced employment levels.

These results hold in both open economy and closed economy versions of the model.

This paper - a product of the Finance and Private Sector Development Division, Policy Research Department - is part of a larger effort in the department to understand private sector development. Copies of the paper are available free from the World Bank, 1818 H Street NW, Washington, DC 20433. Please contact Paulina Sintim-Aboagye, room N9-030, telephone 202-473-8526, fax 202-522-1155, Internet address psintimaboagye@worldbank.org. March 1997. (19 pages)

The Policy Research Working Paper Series disseminates the findings of work in progress to encourage the exchange of ideas about development issues. An objective of the series is to get the findings out quickly, even if the presentations are less than fully polished. The papers carry the names of the authors and should be cited accordingly. The findings, interpretations, and conclusions expressed in this paper are entirely those of the authors. They do not necessarily represent the view of the World Bank, its Executive Directors, or the countries they represent. 


\title{
PRIVATIZATION, PUBLIC INVESTMENT, AND CAPITAL INCOME TAXATION
}

\author{
Harry Huizinga \\ The World Bank and \\ CentER and Department of Economics, Tilburg University" \\ and \\ Soren Bo Nielsen \\ Economic Policy Research Unit \\ Copenhagen Business School
}

Keywords: privatization; capital income taxes

JEL Codes: D24; $\mathrm{H} 21$

- The findings, interpretations, and conclusions expressed in this paper do not necessarily represent the views of the World Bank, its Executive Directors, or the countries they represent. We thank Bev Dahlby, Henri de Groot and seminar participants at the World Bank for comments. 



\section{Introduction}

Historically and across countries, there has been a wide variation in the relative importance of public production. Traditionally, the share of government production in total output has been larger in developing countries than in industrialized countries, with the exception of the centrally planned economies. In recent years, there has been a strong tendency to privatize state-owned enterprises around the world, thereby reducing the share of public production. Wholesale privatization has been underway in Eastern Europe after the collapse of communism. More subtly, the United Kingdom has reduced the share of public production of goods and services for sale in GDP from 6.6 percent in 1982 to 1.9 percent in 1991 , compared to a share of 0.6 percent in the United States in 1987 , and a share of 10.0 in a 'statist' country like France in $1988 .{ }^{1}$ Worldwide, privatization occurs in the belief that it will increase production efficiency and produce welfare gains. Some detailed evidence indeed supports this view (see Boardman and Vining (1989) for a survey).

The present trend towards privatization somewhat obscures the underlying and enduring question of what is the appropriate role of government in production. In 1776 Adam Smith thought that private enterprise was the preferred mode of production. Considering the privatization of crown lands, he writes: "When the crown lands had become private property, they would, in the course of a few years, become well improved and well cultivated."2 Following experiences with excessive capitalism in the 19th century in England and elsewhere, Keynes in 1927 appears to be more of a pragmatist. Considering the boundary between the private and public sectors, he remarks: "The line of demarcation between the two is constantly changing in accordance with the practical needs of the day. As to where precisely this line should be drawn no great question of principle is involved. ${ }^{3}$ Current thinking largely remains pragmatic, although some principles have been enunciated. In a thoughtful essay on the role of the state, Stiglitz (1989) argues that the relative attractiveness of public ownership and production depends on the importance of market failures vs. public failures. Failures in either sector can arise on account of a lack of competition, imperfect information, and incomplete markets. A source of public failures, in addition, may be a government's inability to bind its future actions. Along these lines, several papers have formalized the choice between private and public production. Shapiro and Willig (1990), and Hart, Schleifer, and Vishny (1996) focus on the market failure of incomplete contracts; Bös and Peters (1991) consider the market failure of imperfect competition; finally, Schmidt (1996) considers the public failure of uncommitting governments. While these papers are insightful, they do not offer a workable explanation of, say, cross-country variation in the importance of public production. The 
reason is that countries unable to remedy market failures probably are the same countries unable to remedy public failures.

An important 'market failure,' so far overlooked in this debate, is the taxation of private production by way of income and other taxes. This paper presents a model that explores the implications of taxation for the optimal boundary between the private and public sectors. There is assumed to be a continuum of production activities that in principle can be in the private or public sectors. Unspecified market and public failures for each activity determine the production efficiency of the private sector relative to the public sector, in the absence of any taxation. The public goods nature of defense and the courts, for instance, implies that these activities are best carried out by the public sector. Contracting problems in the public sector, on the other hand, imply that fast food restaurants are best left to the private sector. Other important activities such as education, health services and infrastructure construction and operation, are somewhere in the middle. The key question is where is the optimal dividing line between the public and private sectors. The line of demarcation, in practice, moves following privatization or public take-overs.

The set of tax instruments is assumed to consist of an investment tax, a saving tax, and a non-distorting, but limited profit tax. The government jointly determines tax policy, privatization, and the level of capital investment for publicly-owned activities. The analysis yields several insights. First, the private and public sector each contain those activities where they have an absolute efficiency advantage, if there is no need for distorting taxes on private production. This is the case if the profit tax yields the government sufficient tax revenue. Second, the public sector will be "too large" in the sense that it carries out some activities where it has an absolute efficiency disadvantage, if there is a need for distorting investment taxation. The investment tax renders the private mode of production relatively less attractive, prompting government production to expand into territory where it has a non-tax related efficiency disadvantage. Generally, the size of the public sector is shown to increase with the marginal investment tax distortion. This paper thus provides an economic, non-ideological rationale for the simultaneous reduction of tax burdens and the privatization of state-owned enterprises. At the same time, the analysis begins to offer explanations for the observed variation in the relevance of public production around the world. Highly distortive tax systems in developing countries, for instance, may explain a prevalence of public ownership and production. In addition, international tax competition, to the extent that it explains reductions in corporate income tax levels, also explains privatization in the industrialized countries. Finally, cross-coun:.. veriation in preferences for public goods or redistribution can explain 
different tax levels and state production sectors.

An important focus of the paper is the appropriate level of public investment, thereby extending a sizable literature on the shadow value of public capital (see, for instance, Diamond and Mirrlees (1971a,b), Dasgupta and Stiglitz (1972), Sandmo and Drèze (1971), Hagen (1988) and Stiglitz (1982)). This paper confirms the earlier insight of Sandmo and Drèze (1971) that the appropriate shadow cost of public capital is between the gross return to capital in the private sector, and the net-of-tax return received by savers. This is shown to imply that the government invests more capital in its marginal production activity than the private sector would. As an implication, privatization is accompanied by a shedding of capital.

The remainder of this paper is organized as follows. Section 2 present the model for the case of a small open economy, with access to the international capital market. In the open economy, the shadow cost of public capital is trivially equal to the international interest rate. Next, section 3 analyses the closed economy case where all private and public investment are financed by domestic saving. In this setting, the shadow cost of public capital is shown to reflect the scale of ongoing privatization. Specifically, ongoing privatization moves the shadow cost of public capital closer to the cost of capital in the private sector, and away from the net-of-tax return received by investors. The insight regarding the enlargement of the public sector following the introduction of distorting taxes in the private sector remains valid in this setting. Finally, section 4 concludes by pointing out how the model applies to taxation generally rather than just capital income taxation, and it discusses possible empirical applications.

\section{Privatization in the small open economy}

Consider a two-period framework for a small open economy that takes the international interest rate, $r$, as given. The economy can produce a single, composite good by way of a range of production activities or projects. The total volume of existing production projects is unity. All projects can in principle be carried out either by the public or by the private sector, albeit with generally different technologies. If in the private sector, a project's output if $F(K)$, where $K$ is the project's first-period output and $F(K)$ the second-period output. If in the public sector, the project's output is $(I-\omega) F(K)$, where $\omega$ is the project's relative public waste parameter. This parameter stands for non-tax factors determining the relative production efficiency of the two sectors. With $\omega$ $>0$, the project yields higher output in the private sector (for a given capital input), and vice versa. The parameter $\omega$ is distributed on the interval $[\underline{\omega}, \omega]$ (with $\underline{\omega}<0<\bar{\omega}$ ), with a density 
function $h(\omega)$ and a corresponding distribution function $H(\omega)$.

Below, the public (private) sector specializes in operating projects with low (high) waste parameters $\omega$. Let $\hat{\omega}$ denote the marginal public project that demarcates the line between the two sectors. With $\hat{\omega}=0$, each sector carries out the production activities where it has an absolute efficiency advantage, while with $\omega>0(\omega<0)$ the government sector is "too large" ("too small"). The boundary waste parameter $\hat{\omega}$ is affected by ongoing privatization, or conversely, public take-overs of previously private projects. Hence, the post-privatization boundary, $\omega$, may be different from the original marginal waste parameter, denoted $\omega_{0}$, which reflects original public and private project endowments. With $\hat{\omega}<\hat{\omega}_{0}$, privatization indeed takes place.

In the first period, the representative agent receives an endowment of the single good denoted $Y$. These resources are divided between first-period consumption, $C_{l}$, and saving, $S$. In the second period, there is private consumption, $C_{2}$, and consumption of a public good, $G$. This public good is a one-to-one transformation of the single produced good, and it does not affect the economy's private or public production capacity. To finance the public good, the government can impose a private investment tax at a rate $v$, and a saving tax at a rate $u$, both payable in the second period. In addition, second-period private profits are taxed at a rate $z$, while public profits accrue to the government directly. We assume that the investment tax is deductible from taxable profits. Profits can be thought to reflect some project-specific fixed factor such as land or labor. The feasible profit tax, $z$, is assumed to be limited to the range $0 \leq z \leq \bar{z}<1$. The upper limit on the profit tax may reflect, among other things, that profit taxes beyond a certain level are evaded.

The ordering of events is as follows. First, the government decides on tax rates, the extent of privatization, and public investment levels. Next, private agents make their first-period consumption, saving and private investment decisions. Finally, in the second period the government collects taxes, receives payment for any privatized projects, and production and consumption take place. We will assume that the government requests competitive bids for any projects it wishes to privatize. As a result, the payment that the government receives for privatized projects is equal to the (after-tax) profits of the projects after privatization as follows,

$$
p=\left(\sigma_{p}-\sigma_{p}\right)(1-z)\left[F\left(K_{p}\right)-(1+r+v) K_{p}\right]
$$

where $K_{p}$ is the private capital investment at any private project, and $\sigma_{p}=l-H(\omega)$ $\left[\sigma_{\rho}^{\rho}=1-H\left(\omega_{0}\right)\right]$ is the share of projects in private hands after [before] privatization. These 
shares are loosely referred to as the post- and pre-privatization sizes of the private sector.

The two-period budget constraint of the representative household can be stated as follows,

$$
C_{2} \leq(1+r-u)\left(Y_{1}-C_{1}\right)+\sigma_{p}(1-z)\left[F\left(K_{p}\right)-(I+r+v) K_{p}\right]-P
$$

Second-period consumption, $C_{2}$, thus reflects first-period saving, second-period after-tax profits and the payment to the government for any privatized activities.

The government's second-period budget constraint is as follows,

$$
\begin{aligned}
& G \leq u S+\sigma_{p}\left[z\left[F\left(K_{p}\right)-(1+r+v) K_{p}\right]+v K_{p}\right]+ \\
& \left.\int_{\omega}^{\infty}(1-\omega) F\left(K_{g}(\omega)\right)-(1+r) K_{g}(\omega)\right] h(\omega) d \omega+P
\end{aligned}
$$

where $K_{g}(\omega)$ is the investment at a particular public-sector project. On the income side in (3), the government receives saving, profit and investment tax revenues and the profits from publicly-run projects plus the sales receipts from privatized activities.

The lifetime utility function has an additive form given by $U\left(C_{l}, C_{2}\right)+V(G)$. In the first period, the representative household makes saving and investment decisions, giving rise to the following familiar optimality conditions:

$$
\begin{aligned}
& U_{1}=(1+r-u) U_{2} \\
& F^{\prime}\left(K_{p}\right)-(1+r+v)=0
\end{aligned}
$$

Eq. (5) immediately implies that the private investment, $K_{p}$, is negatively related to the investment tax, $v$, for any private-sector project. Aggregate private and public investments, $\bar{K}_{p}$ and $\bar{K}_{g}$, are given by,

$$
\bar{K}_{p}=\sigma_{p} K_{p}
$$




$$
\bar{K}_{g}=\int_{\omega}^{\infty} K_{g}(\omega) h(\omega) d \omega
$$

To shorten notation, let $\bar{F}\left(\bar{K}_{g} \otimes\right)$ be the maximum public output for a given aggregate government capital, $\bar{K}_{g}$, and projects with waste parameters $\omega \in[\underline{\omega}, \hat{\omega}]$ in the state sector. Note that maximizing government output $\bar{F}\left(\bar{K}_{g} \odot\right.$ ) (for a given capital stock $\bar{K}_{g}$ ) implies that the postwaste marginal product of capital, $(l-\omega) F^{\prime}\left(K_{g}(\omega)\right)$, is constant for all public projects. Specifically, we have $(1-\omega) F^{\prime}\left(K_{g}(\omega)\right)=(1-\omega) F^{\prime}\left(K_{g}(\omega)\right)=d \bar{F}\left(\bar{K}_{g} \omega\right) / d \bar{K}_{g}$ for all $\omega \leq \omega$. This implies that the level of public investment, $K_{g}(\omega)$, for any government project $\omega$ can be written as $K_{g}(\omega)=\left(F^{\prime}\right)^{-1}\left((1-\omega) F^{\prime}\left(K_{g}(\omega)\right)\right) /(1-\omega)$, given an investment, $\frac{K}{\delta}(\hat{\omega})$, in the marginal public project with waste parameter $\omega$. An immediate implication is that the public investment, $K_{g}(\omega)$, for any public project is negatively related to the waste parameter, $\omega$.

Given the private first order conditions (4) and (5), the government wishes to maximize the utility of the representative household, subject to its budget constraint in (3). The government's choice variables are the tax rates $u, v$, and $z$, the volume of public goods, $G$, the boundary parameter, $\hat{\omega}$, and the investment level in the marginal public activity $K_{g}(\hat{\omega})$ (given its linkage to investment levels in other public projects). The government's problem corresponds to the following Lagrangean,

$$
\begin{aligned}
& L=U\left(C_{l},\left(Y_{1}-C_{1}\right)(1+r-u)+\sigma_{p}(1-z)\left[F\left(K_{p}\right)-(1+r+v) K_{p}\right]-P\right)+ \\
& V(G)+\lambda\left(u S+\sigma_{p}\left[z\left[F\left(K_{p}\right)-(1+r+v) K_{p}\right]+v K_{p}\right]+\right. \\
& \left.F\left(\bar{K}_{\delta} \omega\right)+P-G\right)
\end{aligned}
$$

where $\lambda$ is the Lagrange multiplier associated with the government budget constraint. ${ }^{4}$

Rather trivially, the government optimally applies the profit tax, $z$, to the maximum before resorting to distorting saving and investment taxation. Below, therefore, we consider the government's problem of choosing the optimal values of $u, v, \hat{\omega}, K_{g}(\hat{\omega})$, and $G$ for a given (maximum) profit tax, $z$. The corresponding optimality conditions are given by,

$$
-U_{2}+\lambda\left(1-u e_{u}\right)=0
$$




$$
\begin{aligned}
& -U_{2}(1-z)+\lambda\left((1-z)(1+u p)-\rho e_{v} v\right)=0 \\
& (I-\omega) F\left(K_{g}(\omega)\right)-(1+r) K_{g}(\omega)-\left[F\left(K_{p}\right)-(1+r) K_{p}\right]=0 \\
& (I-\omega) F^{\prime}\left(K_{g}(\omega)\right)-(1+r)=0 \\
& V^{\prime}(G)-\lambda=0
\end{aligned}
$$

where $e_{u}=-\frac{d S}{d u} / S \gtrless 0$ is the uncompensated semi-elasticity of saving with respect to the saving tax, $u$ (which is assumed positive at a maximum in (9)); $e_{v}=-\frac{d K}{d v} / K>0$ is the semi-elasticity of private investment with respect to the investment tax, $v ; p$ is the marginal propensity to consume in the first period out of second-period income; and $\rho=\sigma_{p} / \sigma_{p}{ }^{\circ}$ is the relative post-privatization size of the private sector. Note that $\rho>1$ implies ongoing privatization.

Eqs. (9) and (10) rather directly yield the following optimal tax formulae,

$$
\begin{aligned}
& u=\frac{1}{e_{u}}\left(1-\frac{1}{\eta}\right) \\
& v=\frac{1-z}{\rho e_{v}} \frac{e_{u}^{c}}{e_{u}}\left(1-\frac{1}{\eta}\right)
\end{aligned}
$$

where $\eta=\lambda / U_{2}$ is the marginal cost of funds; and $e_{u}^{c}=e_{u}+p$ is the compensated semielasticity of saving with respect to the tax $u$. In standard fashion, eqs. (14) and (15) relate the optimal saving and investment taxes to the saving and investment elasticities. More interestingly, eq. (15) further indicates that the optimal investment tax is negatively related to the relatively postprivatization size of the private sector, $\rho$. In words, the government is ill-advised to levy a high investment tax on private projects, if many of these are newly-privatized. To see why, first note that a higher investment tax on privatized projects by the same amount reduces the sales revenue, $P$, at the time of privatization - for a given private investment level, $K_{p}$. A higher investment tax, however, discourages private investment, thereby reducing the payment, $P$, by more than the additional investment tax revenue intake.

Next, optimality condition (11) guides the government's privatization decision. The condition reflects that, with competitive project pricing, privatization only influences private welfare indirectly through its effe $: \cdots n$ the public budget. In fact, at the optimum the overall 
revenue to the government is maximized. This implies the marginal project's surplus, if in the public sector, equals the project's pre-tax profits, if in the private sector. In (11), however, it is again important to note that private investment, $K_{p}$, is negatively related to the investment tax, $v$. This relationship in effect links the government's optimal tax and privatization problems. To evaluate (11), let us first assume that the available profit tax yields the government sufficient tax revenues. This implies that $\eta=1$, and $u=v=0$. Eq. (5) and (11) together then immediately yield that the optimal boundary parameter $\omega$ equals zero. In this case, there is overall production efficiency, with each of the two sectors holding the projects where it has an absolute production advantage.

More realistically, we next assume that the government has to resort to positive values of the saving and investment taxes, $u$ and $v$, because the marginal cost of public funds, $\eta$, exceeds unity. For this case, we can show: $:^{5}$

Proposition 1. In the open economy, the optimal privatization choice implies

(iii) $\quad v$ and $\omega$ are positively related.

For a proof, see the Appendix. Part (i) of the proposition states that the public sector will be "too large" in that it comprises some projects where it has an absolute efficiency disadvantage with $\eta>1$. Thus the 'market failure' of investment taxation is balanced by the 'public failure' of a marginally inefficient public sector. Part (ii) states that the public sector invests more capital in the marginal public project than the private sector with $\eta>1$. Equivalently, there is underinvestment of capital in the marginal private project because of the investment tax. The investment level for all projects, as related to the public waste parameter $\omega$, are represented in Figure 1. The figure reflects the private-sector underinvestment at the marginal and all other projects. Confirming the private underinvestment result, Moore (1970) provides some evidence that public utilities are more capital-intensive than private utilities. Public utilities, specifically, are shown to have a higher ratio of electricity generating capacity to peak demand than private utilities. Note that part (ii) also implies that the owners of a newly privatized firm will lay off some of the project's capital. Finally, part (iii) indicates that the investment tax, $v$, and the boundary parameter, $\varpi$, are positively related. In words, the optimal size of the public sector is positively related to the 
tax burden on private production. Governments that reduce taxes thus should also be seen to privatize public enterprises for economic, non-ideological reasons.

The linkage between the tax burden on private production and the government's optimal involvement in production has a variety of implications for the optimal scale of public production. Essentially, the economy's underlying technology and preferences, insofar as they justify high taxes on private production activity, also warrant a large government production sector. In the model under consideration, technological and preference parameters can be related to tax and privatization policy as follows,

\section{Proposition 2.}

(i) For given values of $e_{u}^{c},(1-z) / e_{v}$, and $p$, a higher value of $\eta$ leads to larger $u, v$ and $\boldsymbol{\omega}$.

(ii) For given values of $e_{u}^{c}, p, \eta$, a higher value of $(1-z) / e$ increases $v$ and $\hat{\omega}$ while $u$ remains the same.

(iii) For given values of $(I-z) / e_{v}, p$, and $\eta$, a higher value of $e_{u}^{c}$ reduces $u$ and $v$ and $\omega$.

These results follow rather immediately from eqs. (14) and (15), and part (iii) of Proposition 1. Stronger preferences for public goods, for one thing, can give rise to a larger marginal cost of public funds, $\eta$. By part (i) of the proposition, this would give rise to higher saving and investment tax rates, and an expansion of the public sector. Parts (ii) and (iii) reflect that investment and saving elasticities, as they affect the optimal investment and saving tax mix, aiso impact on the optimal size of the public sector. Less elastic private investment demand, reflected in a lower value of $e_{v}$, for instance, can explain a higher investment tax and a larger public sector.

Several other determinants of the optimal investment tax - and hence the size of the public production sector - can be mentioned. First, consider that the government sector becomes more efficient, reflected in lower waste parameters $\omega$, for public activities with $\omega<\omega$. Such public efficiency gains enable the government to obtain higher profits from its public projects. Higher public profits lead to a reduction in the marginal cost of funds, $\eta$, and ultimately to a reduction in the saving and investment tax rates and the size of the public sector, by part (i) of Proposition 2. Finally, it is interesting to consider that domestic private projects or firms are partly foreign-owned. In particular, we can assume that a fraction $\alpha$ of all domestic firms is owned by foreigners, following Huizinga and Nielsen (forthcoming). The foreign ownership of domestic firms, other things equal, renders the investment tax more attractice (relative to the saving tax), as part of the 
incidence of this tax then falls on foreign residents. In fact, the optimal tax problem now implies the following relationship between the investment and saving taxes,

$$
v=\frac{1-z}{\rho e_{v}}\left[(1-\alpha) u e_{u}^{c}+\alpha\right]
$$

From (16), we see that a higher foreign ownership share, $\alpha$, brings about a higher investment tax, $v$, for a given value of $\eta$ (and thus $u$ ), if we assume $1-e_{u}{ }^{c} u>0$. At the same time, it will increase the optimal size of the public production sector. ${ }^{6}$

\section{Privatization in the closed economy}

In the closed economy, the sum of private and public investment has to be financed by domestic saving. In this setting, the domestic interest rate and the shadow cost of public capital are fully endogenous to the government's tax and privatization policies. Issues regarding the optimal public investment have been analyzed in a closed economy setting by, among others, Sandmo and Drèze (1971). They in fact characterize the shadow cost of public capital as a weighted average of the gross return to private investment and the net-of-tax return to saving. This section extends the earlier work on the optimal public investment to incorporate a privatization decision. Two results emerge. First, the findings that the government sector is "too large" with distorting capital income taxation, and that the private sector underinvests continue to hold. Second, the characterization of the shadow value of public capital as a weighted average can be modified in an intuitive way to account for ongoing privatization.

In the closed economy, the tax wedge between the gross return to investment and the net return to saving is denoted $x$. Equivalently, the relevant tax can be imposed on savers or investors. Below, we assume that a single tax, $x$, is levied on the return to saving. The net-of-tax return to saving then is $r-x$, while the cost of capital to investors is $r$. Again, there is a profit tax rate a rate $z$ with $0 \leq z \leq \bar{z}<1$. Note that the saving-investment balance now implies that $S=\bar{K}_{p}+\bar{K}_{g}$. For a given profit tax $z$, the policy variables of interest are the saving tax rate, the public investment in the marginal public project, the size of the state production sector, and the level of public goods provision. The government's optimization problem is stated formally as the following Lagrangean, 


$$
\begin{gathered}
L=U\left(C_{l},\left(Y-C_{l}\right)(1+r-x)+\sigma_{p}(1-z)\left[F\left(K_{p}\right)-(I+r) K_{p}\right]-P\right)+V(G)+ \\
\lambda\left(x S+\sigma_{p} z\left[F\left(K_{p}\right)-(I+r) K_{p}\right]+\vec{F}\left(\mathbb{R}_{z}, \hat{\omega}\right)-(1+r) \bar{K}_{g}+P-G\right)
\end{gathered}
$$

The first order conditions with respect to the policy variables $x, K_{g}(\hat{\omega}), \hat{\omega}$, and $G$ are as follows,

$$
\begin{aligned}
& -U_{2}\left(1-x_{g}^{0} \frac{d r}{d x}\right)+\lambda\left(1-x\left(e_{u}-e_{u}^{0} \frac{d r}{d x}\right)-x_{g}^{0} \frac{d r}{d x}\right)=0 \\
& U_{2} S x_{g}^{0} \frac{d r}{d K_{g}(\omega)}+\lambda\left[\frac{d \bar{K}_{g}}{d K_{g}(\omega)}\left(\frac{d \bar{F}}{d \bar{K}_{g}}-(1+r)\right)+\frac{d r}{d K_{g}(\omega)} S\left(x e_{u}^{0}-K_{g}^{0}\right)\right]=0 \\
& U_{2} S x_{g}^{0} \frac{d r}{d \omega}+ \\
& \quad \lambda\left[\frac{d r}{d \omega} S\left(x e_{u}^{0}-x_{g}^{0}\right)+h(\omega)\left[(1-\omega) F\left(K_{g}(\omega)\right)-(1+r) K_{g}(\omega)-F\left(K_{p}\right)+(1+r) K_{p}\right]\right]=0 \\
& V^{\prime}(G)-\lambda=0
\end{aligned}
$$

where $e_{u}{ }^{0}=e_{u}+p(l-z) q_{p}^{0} K / S$; and $k_{g}^{0}=1-(1-z) \sigma_{p}^{0} K_{p} / S$, with $(1-z) \sigma_{p}^{0} K_{p} / S$ being the effective, after-profit-tax share of capital owned by the private sector with no privatization.

Eq. (18)-(20) reflect that the saving tax, public investment and privatization all affect the domestic interest rate. Imposing saving-investment balance, we find the following relationships,

$$
\frac{d r}{d x}=\frac{e_{s}}{e_{v}\left(\bar{K}_{p} / S\right)}, \frac{d r}{d K_{g}(\omega)}=\frac{l}{\bar{K}_{p} e_{v}+S e_{u}^{0}} \cdot \frac{d \bar{K}_{g}}{d K_{g}(\omega)} ; \frac{d r}{d \omega}=h(\omega) \frac{K_{g}(\omega)-K_{p}}{\bar{K}_{p} e_{v}+S e_{u}^{0}}
$$

Using these relationships and (18)-(20), we can relate the optimal saving tax, $x$, the shadow cost of public investment, $d \bar{F}_{g} / d \bar{K}_{g}$, and the first order condition guiding privatization decisions to the marginal cost of public funds, $\eta$, as follows,

$$
\begin{aligned}
& x=\left[\frac{1}{e_{u}}+\frac{(1-z) e_{u}^{c}}{\rho e_{v} e_{u}}\right]\left[1-\frac{1}{\eta}\right] \\
& \frac{d \bar{F}_{g}}{d \bar{K}_{g}}=1+r-(1-z) \frac{e_{u}^{c}}{\rho e_{v} e_{u}}\left[1-\frac{1}{\eta}\right]
\end{aligned}
$$




$$
(1-\Phi) F\left(K_{g}(\omega)\right)-F\left(K_{p}\right)=\left[1+r-\left(1-\frac{1}{\eta}\right) \frac{(1-z) e_{u}^{c}}{\rho e_{\nu} e_{u}}\right]\left(K_{g}(\omega)-K_{p}\right)
$$

For $\eta>1$, we have $x>0$ in (22). Interestingly, the expression for $x$ in (22) indicates that this saving-investment tax wedge is negatively related to the relatively post-privatization size of the private sector, $\rho$. In words, ongoing privatization lowers the optimal saving-investment tax wedge, as it discourages private investment in newly privatized firms. Next, the expression for the shadow cost of public capital, $d \bar{F} / d \bar{K}_{g}$, in (23) implies that this shadow cost is bounded between the gross cost of capital in the private sector, $l+r$, and the net-of-tax return to savings, $l+r-x$, if $\eta>1$. Using (22)-(23), we can express the cost of public capital, $d \bar{F} / d \bar{K}_{g}$, as a weighted average of the two bounds, $I+r$ and $I+r-x$, with weights $\left[\rho e_{v} /\left(\rho e_{\nu}+(1-z) e_{u}^{c}\right)\right]$ and $\left[(1-z) e_{u}^{c} /\left(\rho e_{v}+\right.\right.$ $\left.\left.(1-z) e_{u}^{c}\right)\right]$, respectively. This characterization of the shadow cost of public capital is a generalization of the main result in Sandmo and Dreze (1971, eq. 19) to include both profit taxation and ongoing privatization. First note that a higher rate of profit taxation, $z$, renders the shadow cost of public investment, $d \bar{F} / d \bar{K}_{g}$, closer to the private cost of capital, $1+r$. Intuitively, a high profit tax makes it less advantageous to raise additional revenue by distorting the private investment decision relative to the shadow cost of public funds. A large relative post-privatization private sector, $\rho$, similarly moves the cost of capital closer to the private cost of capital. From (15), we know that a larger relative post-privatization private sector reduce the stress on investment taxation in the open economy. Analogously, in the closed economy the government then reduces the distortion of private investment relative to the shadow cost of public capital. It is interesting to note that the cost of public capital in the open economy, in particular the gross international interest rate $1+r$, can be expressed also as a weighted average of the gross cost of private capital, $1+r+v$, and the net return to saving, $l+r-u$, with equal weights as in the closed economy.

Next, the government's privatization decision is guided by (24). As before, eq. (24) implies that the public sector only contains those activities where it has an absolute production efficiency advantage if no distorting taxation is used, i.e. if $x=0$. More realistically, there is some distorting taxation with $\eta>1$ in (24). For this case, we can show,

Proposition 3. In the closed economy with $\eta>1$, we have (i) $\square>0$ and (ii) $K_{g}(\hat{\omega})>K_{p}$.

For a proof, see the Appendix. Note that Proposition 3 exactly corresponds to parts (i) and (ii) of Proposition 1. In the closed economy, the government thus also optimally takes on some 
activities where it is relatively inefficient, if the private sector is subject to a positive savinginvestment tax wedge. For the marginal project, the public sector again invests relatively much capital, because the private cost of capital exceeds the shadow cost of public capital. Privatization of a public project thus is followed by a shedding of capital.

\section{Conclusion}

This paper has argued that taxation is a 'market failure' that other things equals render public production more attractive. The theory of optimal taxation therefore can be extended to include a positive theory of the optimal size of the public production sector. This paper is a first step in establishing the link between optimal tax theory and a theory of privatization. The analysis has been limited to capital income taxation. Even in this setting, it will be interesting to see how additional determinants of capital income taxation, such as international tax competition, ultimately affect the optimal size of the public sector. Leaving capital income taxation aside, it should be clear that there also is a direct link between, say, labor income taxation and privatization. With few modifications, the closed economy model of section 3 can in fact be reinterpreted as a model of private and public employment of labor, and labor income taxation. When recast in this manner, the model immediately yields the plausible implication that public firms tends to be relatively labor intensive so that a public firm that is privatized will lay off labor. A link between other areas of taxation and privatization policy can also be envisioned. In future work, it is further possible to be more explicit about the market failures and public failures that together determine the efficient boundary between the private and public sector in the absence of taxation. In any such model, it should remain true that a need to impose distorting taxes on private activity shifts the demarcation line between the two sectors towards a larger public production sector.

The model has several empirical implications. In fact, the model provides a theoretical basis for the common belief that privatization leads to lay-offs (of either labor of capital). Careful case studies of privatization in several countries confirm this (see Galal, et al., 1994). The model also validates other empirical work that has already been done on the performance of public enterprises.

Singh, Ratha and Xiao (1994), for instance, show for a set of Chinese provinces that the productivity of capital in the public sector is positively related to the overall output-share of private firms. The authors argue that this relationship reflect that a larger private sector offers more competition to state-owned enterprises. The model of this paper, however, can equally well explain ihe relationship. Eq. (11) above indeed be checked to yield the theoretical predication that output 
per unit of capital in the public sector is positively related the share of private output in total output, if one varies the investment tax on the private sector. An important prediction of the model, which remains to be tested, is the positive relationship between the tax burden on the private sector and the size of the public sector. Undoubtedly, there is a variety of structural and institutional factors that in practice may explain the size of the public production sector. It will be interesting to see whether taxation is one of them. 


\section{References}

Abe, Kenzo, 1992, Tariff reform in a small economy with public production, International Economic Review, 33, 209-222.

Boardman, Anthony E. and Aidan R. Vining, 1989, Ownership and performance in competitive environments: a comparison of the performance of private, mixed, and state-owned enterprises, Journal of Law and Economics 32, 1-33.

Bös, Dieter, and Wolfgang Peters, 1991, Privatization and Public Enterprises, Empirica 18, 5-16.

Dasgupta, Partha and Joseph Stiglitz, 1972, On optimal taxation and public production, Rsview of Economic Studies, 87-103.

Diamond, Peter A. and James A. Mirrlees, 1971a, Optimal taxation and public production efficiency I: production efficiency, American Economic Review 61, 8-27.

Diamond, Peter A. and James A. Mirrlees, 1971b, Optimal taxation and public production II: tax rules, American Economic Review 61, 261-278.

Galal, Ahmed, Leroy Jones, Pankaj Tandon, and Ingo Vogelsang, 1994, Welfare consequences of selling public enterprises, an empirical analysis (Oxford University Press).

Hagen, Kàre P., 1988, Optimal shadow prices for public production, Journal of Public Economics $35,119-127$.

Hart, Oliver, Andrei Shleifer and Robert W. Vishny, 1996, The proper scope of government: theory and an application to prisons, NBER WP No. 5744.

Huizinga, Harry and Søren Bo Nielsen, Capital income and profit taxation with foreign ownership of firms, forthcoming in Journal of International Economics.

Keynes, John Maynard, 1981, The collected writings of Johan Maynard Keynes, Donald Moggridge, ed. (Macmillan, Cambridge University Press).

Moore, Thomas G., 1970, The effectiveness of regulation of electric utility prices, Southern Economic Journal 36, 365-375.

Sandmo, Agnar and Jacques Drèze, 1971, Discount rates for public investment in closed and open economies, Economica 38, 395-412.

Schmidt, Klaus M., 1996, Incomplete contracts and privatization, European Economic Review 40, 569-579.

Shapiro, Carl, and Robert D. Willig, 1990, Economic rationales for the scope of privatization, in: Ezra N. Suleiman and John Waterbury, eds., The political economy of public sector reform and privatization (Westview Press, Boulder $\mathrm{CO}$ ).

Singh, Inderjit, Dilip Ratha, and Geng Xiao, 1994, Non-state enterprises as an engine of growth: an analysis of provincial industrial growth in post-reform China, School of Economics and Finance DP No. 157, The University of Hong Kong. 
Smith, Adam, 1950, The wealth of nations, Edwin Cannan, ed. (Methuen, London).

Stiglitz, Joseph E., 1982, The rate of discount for benefit/cost analysis and the theory of the second best, in Lind, Robert E., ed., Discounting for time and risk in energy projects.

Stiglitz, Joseph E. et al., 1989, The economic role of the state (Basil Blackwell, Oxford).

World Bank, 1995, Bureaucrats in business, the economics and politics of government ownership, Oxford University Press, Oxford. 


\section{Appendix}

\section{Proof of Proposition 1:}

(i) Eq. (11) implies that

$$
\Delta=(1-\infty) F\left(K_{g}(\omega)\right)-(1+r) K_{g}-\left[F\left(K_{p}\right)-(1+r) K_{p}\right]=0
$$

Note that with $\omega=0$, we have $\Delta>0$, as the private investment, $K_{p}$, is distorted by the investment tax, $v$. To see the result, note that $d \Delta / d \omega=-F\left(K_{g}(\omega)\right)<0$.

(ii) From (11) and $\omega>0$, we see that,

$$
F\left(K_{g}(\Phi)\right)-(1+r) K_{g}(\Phi)>F\left(K_{p}\right)-(1+r) K_{p}
$$

The result follows by noting that $F^{\prime}\left(K_{p}\right)-(1+r)>0$ from (5).

(iii) Totally differentiating (11), we find that,

$$
\frac{d \omega}{d v}=-\frac{\left[F^{\prime}\left(K_{p}\right)-(1+r)\right]\left(d K_{p} / d v\right)}{F\left(K_{g}(\omega)\right)}>0
$$

\section{Proof of Proposition 3:}

Defining $\Delta$ as

$$
\Delta=(I-\hat{\omega}) F\left(K_{g}(\hat{\omega})\right)-(I+r-\xi) K_{g}(\hat{\omega})-\left[F\left(K_{p}\right)-(I+r-\xi) K_{p}\right]=0
$$

with

$$
\xi=\left(1-\frac{1}{\eta}\right) \frac{(1-z) e_{u}^{c}}{\rho e_{\nu} e_{u}}
$$

the proof is parallel to that for (i) and (ii) of Proposition 1. 
1. See the World Bank (1995), Table A.1, pp. 268-271. This source provides comparable data on the share of public production in GDP for 82 countries for the years 1978-91. The data relate to non-financial government production by firms that generate the bulk of their revene from selling goods and services, excluding education, health services, and road construction and maintenance (see p. 26).

2. See Adam Smith (1950) vol. 2, p. 309.

3. Keynes (1981) vol. 19, part 2, p. 695.

4. In (8) the constraints on the profit tax rate, $z$, are ignored.

5. Note that it is possible that $\eta<1$ with optimally $z=0$. This occurs if the profits that the government obtains from running public projects with $u=0, v=0$, and $\omega=0$ exceed the corresponding optimal provision of public goods, $G$. In this instance, optimal policy implies $x<0, v<0$ and $\omega \div 0$, which implies that the state sector is "too small". This somewhat irrealistic case is ignored.

6. A larger foreign ownership share $\alpha$, however, tends to reduce the cost of public funds, precisely because part of the incidence of the investment tax now is on foreign owners. This tends to lower $v$. The net effect on the investment tax rate and the size of the public sector is, therefore, ambiguous. 
Figure 1: Investment levels in public and private sectors

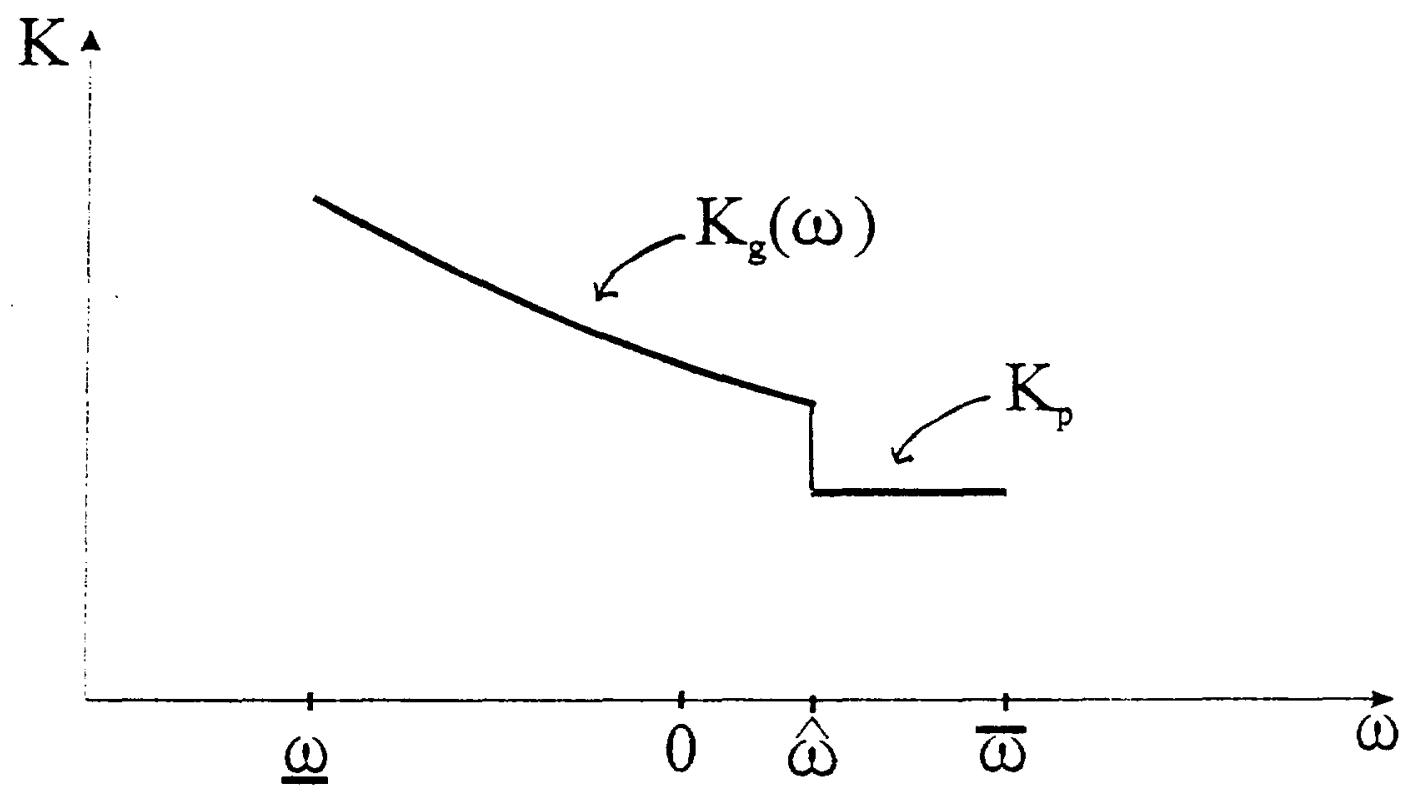





\section{Policy Research Working Paper Series}

Title

WPS1719 Shifting Responsibility for Social Services As Enterprises Privatize in Belarus

WPS1720 The Distribution of Foreign Direct Investment in China

WPS1721 EU Accession of Central and Eastern Europe: Bridging the Income Gap

WPS1722 Uncertainty, Instability, and Irreversible Investment: Theory, Evidence, and Lessons for Africa

WPS1723 The Productivity Effects of of Decentralized Reforms: An Analysis of the Chinese Industrial Reforms

WPS1724 Debt Maturity and Firm Performance A Panel Study of Indian Companies

WPS1725 Access to Long-Term Debt and Effects on Firms' Performance: Lessons form Ecuador

WPS1726 Roads, Population Pressures, and Deforestation in Thailand, 1976-89

WPS1727 The Economics of the Informal Sector: A Simple Model and Some Empirical Evidence from Latin America

WPS1728 Regional Labor Markets during Deregulation in Indonesia: Have the Outer Islands Been Left Behind?

WPS1729 Does Mercosur's Trade Performance Raise Concerns about the Effects of Regional Trade Arrangements?

WPS 1730 Have Trade Policy Reforms Led to Greater Openness in Developing Countries?

WPS1731 Pension Reform, Growth, and the Labor Market in Ukraine
Author

Date

Contact

for paper

David Sewell

February 1997

C. Lawrence 32216

Harry G. Broadman

Xiaolun Sun

Luca Barbone

Juan Zalduendo

Luis Servén

February 1997

E. Khine

37471

Lixin Colin Xu

February 1997

Fabio Schiantarelli

Vivek Srivastava

Fidel Jaramillo

Fabio Schiantarelli

Maureen Cropper

Charles Griffiths

Muthukumara Mani

Norman V. Loayza

February 1997

R. Martin 39026

Chris Manning

Alexander Yeats

February 1997

J. Ngaine 37947

Shuby Andriamananjara John Nash

February 1997

J. Ngaine 37959

Michelle Riboud

Hoaquan Chu
February 1997

R. Hablero 33971 


\section{Policy Research Working Paper Series}

Title

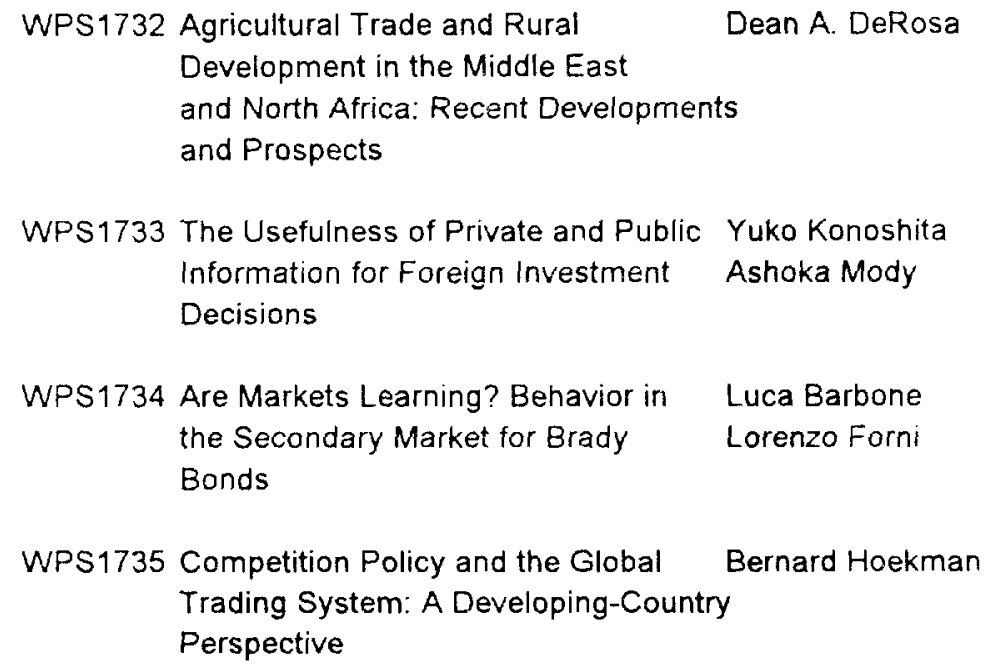

Yuko Konoshita

Ashoka Mody

Date

February 1997

lan Alexander

Simeon Djankov

Gernard Pohl

Gaurav Datt

Dileni Gunewardena

Gerard Caprio, JI

March 1997

March 1997

March 1997

February 1997

February 1997

March 1997

March 1997

March 1997

March 1997
Contact

for paper

J. Ngaine 37959

R. Reff

34815

L. Barbone 32556

J. Ngaine 37949

R. Schneiderman 30191

A. Ramirez 85734

B. Moore 38526

R. Martin 39026

P. Sintim-Aboagye 38526 